\title{
Policy for Overcoming Digital Inequality: Structure, Actors and Technologies
}

\author{
Inna Miroshnichenko ${ }^{1}$ Elena Morozova ${ }^{1, *}$ Elena Meshcheryakova ${ }^{1}$
}

\author{
${ }^{1}$ Department of Management and Psychology, Kuban State University, Krasnodar, Russia \\ *Corresponding author.morozova_e@inbox.ru
}

\begin{abstract}
The article aims at specifying the structure of policy for overcoming digital inequality, which is a serious challenge for public authorities under current conditions. Based on a theoretical model of three levels of digital inequality and empirical analysis of a wide range of sources, the authors mark out the main actors of the policy and consider its basic technologies.
\end{abstract}

Keywords: digital inequality, policy for overcoming digital inequality, digitalization, digital inclusion, State

\section{INTRODUCTION}

Rapid digitalization of all spheres of social life have favored mainstreaming of the issue of digital inequality, which has a complex and multidimensional nature and a direct impact on the process and results of sustainable development of modern countries, in scientific discourse.

Digital inequality is growing not only between countries but also between cities and rural settlements, wealthy and poor categories of citizens inside the country, between young and elderly people, persons with disabilities and healthy people. It limits people in their job search, social networking and cultural exchange.

Modern countries, including Russia, have faced challenges and consequences of digital development which have aggravated due to the COVID-19 pandemic. In a short timeframe, countries all across the globe had to propose and adopt efficient digital solutions that allow to rearrange the activities of the population and organizations of public, commercial and non-profit sectors, the success of which is determined by the level of their digital inclusion.

The research relevance for the political and managerial sphere is explained by a critical need for searching efficient models and resources for development of digital inclusion policy, ensuring consistent coordination between digital strategies and the sustainable development goals of modern Russia. The major challenges for the system of public administration include, firstly, the possibility of accumulation of different types of social inequality and emergence of new divides, secondly, the existing divide

*Fund: The research was supported by the Russian Foundation for Basic Research. Project № 18-011-00975 «Subjective space of politics: opportunities and challenges of network society». between the levels of digital competence of the political and administrative elite and citizens, thirdly, the need for transformation of educational infrastructure, favouring continuous digital literacy education and corresponding to constant IT development, fourthly, the impact of digital inequality on the image and reputation capital of the State.

Writer P. Gilster was one of the pioneers in developing the issues of digital inequality. He was the first to introduce the term 'digital literacy', and his book Digital Literacy was the world's first monograph about digital literacy and digital inequality. He paid attention to the skill of understanding and using information, presented in plenty of different formats and in a wide range of sources, with the use of computers and the Internet [1]. P. Himanen and M. Castells addressed the notion of digital inequality in their book The Information Society and the Welfare State: The Finnish Model. In his fundamental work The Information Age: Economy, Society and Culture [2], M. Castells defined unequal access to the Internet as a 'digital divide' from the sociological point of view. Researcher M. Leaning marked out three main causes of digital inequality - the ability to use digital technology and the Internet, including financial expenses for permanent connection to the Internet, necessary devices and so on; the necessary level of digital literacy; the specificity of using digital media and devices they are installed on [3]. In her paper Conceptualization of Digital Divide: Major Stages, E.L. Vartanova [4] marks out three stages of the evolution of studies on digital inequality. The first stage focuses on studying the issue of network access, the second stage describes the impact of digital inequality on social life, and the third stage covers the studies on new types of ICT-driven inequalities. N.V. Plotichkina, E.V. Morozova and I.V. Miroshnichenko [5] consider 
the term 'digital inclusion' from the political and managerial point of view.

\section{RESEARCH METHODOLOGY}

The main methodological approaches of the study are network, neo-institutional and comparative approaches. The network methods allow to specify the content, dynamics, subjects and results of networkization and digitalization of modern society under the influence of information and communication technology. From the perspective of the neoinstitutional approach, policy for overcoming digital inequality is considered as a targeted consistent activity of the State that creates conditions for development of citizen's institutional practices in different spheres of social life on the basis of digital resources and skills. Broad empirical comparison of subjects, mechanisms and tools, results and factors of the development of digital inclusion policies under modern countries' conditions will be carried out on the basis of methodological principles of the comparative approach.

The study is based on a theoretical model of three levels of inequality: the first level of digital divides is conditioned by Internet access (technological inequality); the second level is determined by a degree of mastering digital competencies by citizens and user's personal motivation (differences in skills of online users); the third level shows itself in differentiation of efficiency and productivity of using digital technologies by citizens for various purposes (benefits and results, obtained by users in their professional, social, economic, cultural and political activities). This model, proposed by E. Helsper, is based on formation and development of institutional mechanisms of digital inclusion policy, aimed at solving problems encountered in the 'real' lives of groups of users that were "excluded" as a result of digital divides.

Digital inclusion policy practices of modern countries were specified and assessed through descriptive analysis of open data of analytical and research centres and through the use of comparative rankings of countries and statistical sources, including the OECD Skills Outlook 2019: Thriving in a Digital World, UNCTAD reports Building Digital Competencies to Benefit From Frontier Technologies and Digital 2020, standards of the information literacy competence for higher education, a digital skills toolkit, developed by the International Telecommunication Union, Statcounter ranking, OECD roadmap Measuring the Digital Transformation and analytical reports by GlobalWebIndex. The motivational and social levels of digital inequality were studied with the use of secondary analysis of sociological data, published on such resources as the Joint Economic and Social Data Archive (http://sophist.hse.ru/arch_about.shtml), World Values (https://www.worldvaluessurvey.org/wvs.jsp),

European Values Study (EVS) (https://europeanvaluesstudy.eu/), Eurobarometer (https://ec.europa.eu/commfrontoffice/publicopinion/in dex.cfm) and Pew Global Attitudes Survey (https://www.pewresearch.org/global/questionsearch/?qid=365\&cntIDs=\&stdIDs=)

\section{STRUCTURE OF POLICY FOR OVERCOMING DIGITAL INEQUALITY}

Digital inclusion policy practices in modern countries are identified and described on the basis of a theoretical model of three levels of inequality: the first level of digital divides is conditioned by Internet access (technological inequality); the second level is determined by a degree of mastering digital competencies by citizens and user's personal motivation (differences in skills of online users); the third level shows itself in differentiation of efficiency and productivity of using digital technologies by citizens for various purposes (benefits and results, obtained by users in their professional, social, economic, cultural and political activities) [6].

The proposed model of three levels of inequality not only differentiates the existing practices but also traces the evolution of formation and development of policies for overcoming digital inequality in modern countries. The evolution of policy for overcoming digital inequality has several reference points, determining the specificity of its stages.

The first stage of the formation of policy for overcoming digital inequality, which started in 1995 with a report of the US National Telecommunications and Information Administration [7], is connected with addressing the issue of providing the population with infrastructure access to information and communication technologies as part of the life maintenance system of any settlement in the country. This issue was being updated in political agendas of a number of countries (USA, Australia, the UK, Canada, Japan, South Korea, India, China and EU countries [8]) under the influence of a rapidly developing digital infrastructure (from the introduction of personal computer services with broadband and satellite Internet to $5 \mathrm{G}$ high-speed mobile Internet). It is important that if a current issue of concern for the countries that were pioneers in developing digital infrastructure is to improve its quality, $40 \%$ of the world population - almost 3.2 billion people, mostly citizens of African and South Asia countries - still have a pressing need for Internet access [9].

The content of practices of the second stage (early 2000s) of the development of policy for overcoming digital inequality in modern countries is based on citizen's digital competencies, which was the key 
agenda at the World Summit on the Information Society (WSIS) [10]. According to the studies on measuring the skills of practical use of information and communication technologies, conducted by E. Hargittai in 2002, the skills of seeking and finding different types of information on the Internet turned out to be fundamental and determining the citizen's efficient use of digital infrastructure. Empirical studies demonstrated significant differences in the efficiency of ICT practical use depending on the age, experience of work with the technologies and the level of education among the experiment participants who had Internet access [11], [12], [13], which finally became a subject for developing new institutional measures in modern countries within the competence stage of policy for overcoming digital inequality.

The third stage (early 2010s) of the evolution of policy for overcoming digital inequality in modern countries is based on the development of institutional mechanisms of digital inclusion policy, aimed at solving problems encountered in the 'real' lives of groups of users that were "excluded" as a result of digital divides. Digital inclusion policy started being implemented quite actively in EU member states' practices. The European Commission proposed its Digital Competence Framework for Citizens (DigComp) which serves as a reference standard for the EU states. Digital competence is understood as the confident, critical and creative use of modern technologies in everyday life. DigComp implies five areas: information and data literacy (browsing, searching and filtering, evaluating and managing online content); communication and collaboration through digital technologies (sharing data, network civic engagement, netiquette, managing digital identity); digital content creation; digital safety; problem solving (creatively using digital technologies, identifying digital competence gaps) [14]. DigComp helps politicians develop strategies for improving digital competencies in Europe, providing them with a "common language" of definitions for IT skills.

Digital skills inequality aggravates inequality between developing and developed countries, between social groups [7]. E. Helsper states that successful digital inclusion initiatives start and end with the tangible outcomes. That is why policy for disseminating digital technologies is focused on solving problems encountered in the "real' lives of "online excluded" groups [15]. The importance of digital skills for citizens becomes evident in identifying advantages and tangible outcomes, obtained in mastering and applying ICT. These very skills are a key factor that determine people's ability to transform the use of web resources into real benefits (for example, advantages in getting a job, e-learning or using public and municipal services online).
As a rule, digital competence development initiatives are part of national digital strategies, for example, the UK Umbrella Digital Strategy that focuses on the development of digital infrastructure, skills, entrepreneurship, security, government, data economy [16], Bulgaria's programme Digital 2020, Canada's Innovation and Skills Plan [17] and so on.

"Digital leaders" of Northern Europe (Belgium, Denmark, Estonia, Finland, the Netherlands, Sweden) have implemented activities for cultivating digital skills in their strategies and prioritized them [18]. National digital strategies shall guarantee general domain of basic digital skills (individual digital literacy), necessary for living in digital society, and provide opportunities for mastering intermediate and specialized skills that improve employment prospects [19]. As a response to digital transformations, 32 countries of the OECD and 6 partner countries developed national digital strategies, agendas or programmes [20], correlating with the Digital Agenda for Europe, Digital Single Market Strategy for Europe, Europe 2020 Strategy and European eGovernment Action Plan.

\section{ACTORS AND TECHNOLOGIES OF POLICY FOR OVERCOMING DIGITAL INEQUALITY}

Taking advantages of digital transformation efficiently finally depends on the State's ability to develop a set of policies, involving the State itself, business structures and non-profit organizations which will help the population adapt to changes and master IT competencies. The State has a wide range and variety of functions in digital inclusion policy, depending on its institutional model (from an integrated approach to national programmes on building digital competencies in Canada and the umbrella model, implying the development of digital infrastructure, skills, entrepreneurship, security, government and data economy in the UK, to the US policy of nonintervention of the State in digital development, implying stimulation of competition at the market of Internet service providers). Most of the countries that implement digital inclusion policy determine a package format of programmes and institutional mechanisms, aimed at financial support measures (subsidies) for disadvantaged social groups and territories [20] (Austria, Canada, China, Israel, etc.) in modern digital infrastructure, to implementation of digital literacy programmes both in the system of general education and within their strategies of ICT skills development, meant for all categories of the population and all levels of specialization - from basic skills to the training at the level of advanced technology research. As a rule, businesses (mostly Internet service providers) get involved into digital inclusion policy within the framework of corporative strategies of digital 
infrastructure development in certain territories. For example, private companies may offer their digital transformation roadmaps for the regions where they build, for example, IT infrastructure (Realising Digital Myanmar Plan of Norwegian company Telenor, covering seven areas - digital legislation, infrastructure, ecosystem, skills, government, businesses and consumption) [21]. The State, businesses and non-profit organizations successfully implement joint educational programmes for different categories of the population, integrated into the activities of various public platforms (libraries, co-working centres and makerspaces) or professional associations and charitable organizations in countries of Europe, North and South America within national strategies of digital development [22].

Technologies for implementing policies for overcoming digital inequality can be classified by several criteria: a) by spheres of application economic, infrastructure, educational, etc.; b) by the scale of application - nationwide, regional and local; c) by their nature - universal and unique; d) by their focus on target groups (children, the youth, elderly people, teachers, etc.). Let us consider an example of a technology for subsidizing low-income families, purchasing computers, which is put into action in Austria, Canada, China, Columbia, Costa Rica, Israel, etc. Brazil ensures tax concessions for buying smartphones, Denmark and Poland - for purchasing services of wideband connection [20]. This is a nationwide technology, implemented in the economic sphere, a universal technology that is meant for a specific target audience - low-income families. Russia implements programme Grandparents On-line which has helped thousands of elderly people master IT technologies and learn to get public services online [23]. This national social programme, aimed at digital socialization of elderly people, is implemented by the Association of Veterans, Persons with Disabilities and Elderly People, an interregional social organization. This is a nationwide educational technology, unique by its nature and focused on the target audience of elderly people.

\section{CONCLUSION}

Modern understanding of digital inequality is connected not so much with the issue of Internet access as with the user's ability to apply digital technology for improving his/her life. Unified interpretation of digital skills models and the presence of universal methods for collecting data on IT literacy favours proper assessment of the efficiency of digital inclusion policy which is carried out according to such key parameters as access, skills, motivation and interaction (trust). Digitalization of economy and society requires transformation of educational infrastructure, favouring continuous digital literacy education and corresponding to the constant development of IT technologies.
Policy for overcoming digital inequality and of digital inclusion is actually of a mixed nature - on the one hand, the role of the State as a leading actor of digital socialization that must provide all the citizens with access to digital technologies, is increasing, and on the other hand, a socializing intersubject effect on the population that is mostly alienated from digital technologies is being activated. Eventually, this policy is focused not on the development of digital infrastructure or skills but on ensuring socially tangible outcomes of online interaction, obtained by citizens (increment of economic, cultural and other forms of capital) due to the use of web resources, and on solving problems encountered in everyday lives of "online excluded" groups.

In the near future, the degree of success of development and implementation of policies for overcoming digital inequality will be connected with implementation of an integrated approach, allowing to consider changes, connected with digital transformation in all spheres of social life in a certain country. This approach implies "umbrella" incorporation of this policy into all areas of public policy (educational, social, economic and others), the development of which is impossible without consideration of citizen's digital skills. Besides, a model policy on alleviating digital inequality implies a multi-level nature of organizing public programmes, taking into account the regional and local specificity of digital infrastructure and digital inclusion of citizens into various activities, as well as tasks on sustainable development of territories. Digital inclusion policy achieves its maximum efficiency in case of successful intersectoral interaction, when the State unites its efforts with businesses, social organizations, foundations and cultural institutions.

\section{References}

[1] P. Gilster. Digital literacy. New York: Wiley, 1997.

[2] M. Castells. The Information Age. Moscow: State University "Higher School of Economics", 2000.

[3] M. Leaning. Digital Divides: Access, Skills and Participation // Media and Information Literacy: An Integrated Approach for the 21st Century. Chandos Publishing, 2017, pp. 101-114.

[4] E. L. Vartanova. Conceptualization of Digital Divide: Major Stages // MediaAlmanah Journal. - 2018. No. 5, pp.8-12.

[5] N. Plotichkina, E. Morozova, I. Miroshnichenko. Digital Technologies: Policy for Improving Accessibility and Usage Skills Development in Europe and Russia // World Economy and International Relations. - 2020. Vol. 64, No. 4, pp. 72-85.

[6] A. J. A. M. Van Deursen, E. Helsper, R. Eynon, J. A. G. M. van Dijk. The Compoundness and Sequentiality of Digital Inequality // International Journal of Communication. - 2017, No. 11, pp. 452-473.

[7] Connecting the Nation: Libraries and Health Care Organizations in the Information Age: Prepared by National Telecommunications and Information Administration, June 28, 1995. URL: http:// www.ntia.doc.gov/report/1995/connecting- 
nation-libraries-and-health-care-organizations-information-age (accessed 09.05.2020).

[8] Digital around the World in 2020. URL https://wearesocial.com/digital-2020 (accessed 02.05.2020).

[9] The "Next Billion": Unconnected Audiences. ITU; GlobalWebIndex; GSMA Intelligence; Eurostat; Social Media Platforms' Self-Service Advertising Tools; Local Government Bodies and Regulatory Authorities; APJII; Kepios Analysis URL: https://www.web-canape.ru/files/352/map-of-the-worldsdigital.png (accessed 10.05.2020).

[10] World Summit on the Information Society, 10-12 December 2003, Geneva. URL: http://www.itu.int/wsis/geneva/index.html. (accessed 10.05.2020).

[11] E. Hargittai. Second-Level Digital Divide: Differences in People's Online Skills // First Monday. - 2002, Vol. 7, No. 4.

[12] J. Van Dijk. The Evolution of the Digital Divide. The Digital Divide turns to Inequality of Skills and Usage // Digital Enlightenment Yearbook. - 2012, pp. 57-75.

[13] Trade and Development Report, 2002: United Nations Conference on Trade and Development, Geneva. URL: http://unctad. org/en/docs/tdr2002_en.pdf. (accessed 10.05.2020)

[14] S. Carretero, R. Vuorikari, Y. Punie. DigComp 2.1: The Digital Competence Framework for Citizens with Eight Proficiency Levels and Examples of Use. Luxembourg, Publications Office of the European Union, 2017. DOI: 10.2760/38842 URL: https://publications.jrc.ec.europa.eu/repository/bitstream/JRC10 6281/web-digcomp2.1pdf_(online).pdf (accessed 03.02.2020).

[15] E. Helsper, A. J. A. M. van Deursen. "Digital Skills in Europe: Research and Policy", in Digital Divides. Andreasson K. Boca Raton, Ed. CRC Press, Taylor \& Francis Group, 2015, p. 128.

[16] UK Digital Strategy $2017 . \quad$ URL: https://www.gov.uk/government/publications/uk-digitalstrategy/uk-digitalstrategy (accessed 29.12.2019).

[17] Building Digital Competencies to Benefit from Frontier Technologies. UNCTAD New York, United Nations Publications, 2019.
URL: https://unctad.org/en/pages/PublicationWebflyer.aspx?publicati onid=2449 (accessed 29.12.2019).

[18] J. Orlik, J. Casasbuenas, K. Helkkula. Digital Frontrunners Designing Inclusive Skills Policy for the Digital Age. London, NESTA, $2018 . \quad$ URL: https://media.nesta.org.uk/documents/Digital_Frontrunners_We b.pdf (accessed 29.12.2019).

[19] International Telecommunication Union. Digital Skills Toolkit. Geneva, ITU, 2018. URL: https://www.itu.int/en/ITUD/Digital-

Inclusion/Documents/ITU\%20Digital\%20Skills\%20Toolkit.pdf (accessed 29.12.2019).

[20] OECD Digital Economy Outlook 2017. Paris, OECD Publishing, $2017 . \quad$ URL: http://dx.doi.org/10.1787/9789264276284-en (accessed 29.12.2019)

[21] Realising Digital Myanmar. Leapfrogging to an Inclusive Digital Economy. URL: https://www.telenor.com/wpcontent/uploads/2018/02/Telenor-Realising-Digital-MyanmarReport-06-February.pdf (accessed 29.12.2019).

[22] Digital Inclusion Reports and Resources (ITU). URL: https://www.itu.int/en/ITU-D/DigitalInclusion/Pages/Reports_and_Resources.aspx (accessed 29.12.2019).

[23] Official Website of National Social Program Grandparents Online. URL: http://babushka-on-line.ru (accessed 29.12.2019). 